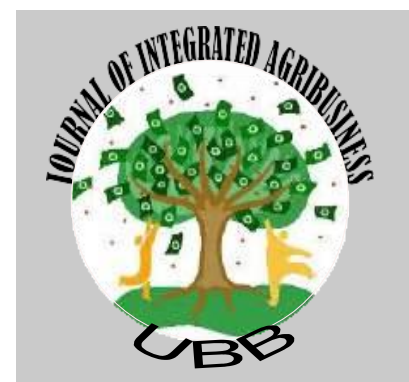

\title{
Journal of IntegratedAgribusiness
}

\author{
Website Jurnal : http://jia.ubb.ac.id/ \\ Publikasi Artikel Penelitian
}

\section{Analysis of Structure, Conduct, and Performance (SCP) In Marketing of White Pepper (Muntok White Pepper) In Bangka Regency}

\section{Analisis Structure, Conduct, and Performance (SCP) pada Pemasaran Lada Putih (Muntok White Pepper) di Kabupaten Bangka Barat}

\author{
Chatijah Adha a ${ }^{*}$ Yudi Sapta Pranotob, Rati Purwasihc \\ abcJurusan Agribisnis, Fakultas Pertanian Perikanan dan Biologi \\ Universitas Bangka Belitung, Bangka, Indonesia \\ Email Korespondensi: chatijahadha612@gmail.com
}

\begin{abstract}
ABSTRACK
White pepper is a plantation commodity that plays an important role in export and import activities the marketing aspect is important in the cultivation of smallholder pepper plantations. White pepper farming is carried out regularly and continuously in West Bangka Regency supported by the potential of white pepper that has a brand image (Muntok White Pepper). In running white pepper farming, there in a need for marketing efficiency analysis. The objectives of this research are (1) describe the white pepper marketing channel in West Bangka Regency, (2) analyze the efficiency of white pepper marketing using market structure, market conduct, and market performance (SCP) methods in Bangka Regency. This research was conducted by survey method. The analytical tool used was descriptive qualitative and SCP approach. The results showed that there were five types of white pepper marketing channels in West Bangka Regency. The market structure formed from domestic white pepper marketing to imperfect competition markets namely oligopoly, Marketing channel 4 is a relatively more efficient channel measured based on the smallest margin value of $R p 4.000$, Farmer's Share of 92,59 and R/C ratio of 2,63.
\end{abstract}

Keywords: Market Conduct; Marketing Efficiency; Market Performance; Market Structure; White Pepper

\section{ABSTRAK}

Lada Putih merupakan komoditas perkebunan yang berperan penting dalam kegiatan ekspor dan impor. Aspek pemasaran merupakan hal penting dalam pengusahaan perkebunan lada rakyat. Usahatani lada putih dilakukan secara berkala dan berkelanjutan di Kabupaten Bangka Barat didukung oleh potensi lada putih yang telah memiliki brand image (Muntok White Pepper). Dalam menjalankan usahatani lada putih maka perlu adanya analisis efisiensi pemasaran. Tujuan penelitian ini adalah (1) Mendeskripsikan saluran pemasaran lada putih di Kabupaten Bangka Barat, (2) Menganalisis efisiensi pemasaran lada putih menggunakan metode market strukture, market conduct, and market performance (SCP) di Kabupaten Bangka. Penelitian ini dilakukan dengan metode survei. Alat analisis yang digunakan adalah deskriptif kualitatif dan pendekatan SCP. Hasil penelitian menunjukan bahwa terdapat lima macam saluran pemasaran 
lada putih di Kabupaten Bangka Barat. Struktur pasar yang terbentuk dari pemasaran lada putih dominan ke pasar persaingan tidak sempurna yaitu oligopoli. Saluran IV merupakan saluran yang relatif lebih efisien di ukur berdasarkan nilai margin terkecil yakni Rp 4.000, Farmer's share sebesar 92,59, dan R/C rasio sebesar 2,63.

Kata Kunci: Perilaku Pasar; Efisiensi Pemasaran; Kinerja Pasar; Struktur Pasar; Lada Putih

\section{PENDAHULUAN}

Lada (Piper ningrum L.) merupakan komoditas perkebunan yang berperan penting dalam kegiatan ekspor dan impor. Indonesia adalah pemasok utama lada hitam dan putih ke pasar Amerika Serikat dengan tingkat pengiriman sebesar 20.423 ton (47 persen), diikuti oleh Brazil dengan tingkat pengiriman sebesar 8.715 ton (20 persen), Vietnam dengan tingkat pengiriman sebesar 7.963 ton (18 persen) dan India sebesar 5.600 ton (13 persen) (Bappebti, 2014). Provinsi Kepulauan Bangka Belitung menempati urutan pertama penghasil lada terbesar di Indonesia dengan jumlah produksi sebesar 32.352 ton/tahun, diikuti dengan Provinsi Lampung dengan jumlah sebesar 14.830 ton/tahun, kemudian Provinsi Sumatera Selatan dengan jumlah sebesar 8.855 ton/tahun. Pada tahun 1987 hingga 2002 merupakan masa kejayaan lada putih dengan produksi mencapai sekitar 80-97 persen atau 62.000 ton per tahun dari total produksi lada putih Indonesia. Bahkan lada putih menjadi komoditi ekspor dengan negara tujuan yakni Amerika Serikat, Singapura, Eropa, Jepang dan negara lainnya. Ekspor lada putih tertinggi terjadi pada tahun 2000, yaitu sebanyak 34.256 ton yang merupakan lada putih asal Provinsi Bangka Belitung (Asmarantaka, 2009). Dewasa ini, kejayaan lada putih tersebut mulai memudar dan be- berapa tahun belakangan ekspor lada putih semakin menurun. Penurunan ekspor lada putih terjadi dari tahun 2014 hingga 2017 dimana pada tahun 2014 jumlah ekspor lada putih sebesar 96.812,21 ton/tahun dan pada tahun 2017 sebesar 36.425,58 ton/tahun. Penurunan ini sejalan dengan menurunnya produktivitas lada putih. Tingkat produktivitas pada tahun 2013 sebesar 1,64 ton/ha, tahun 2014 sebesar 1,53 ton/ha, tahun 2015 sebesar 1,26 ton/ha, tahun 2016 sebesar 1,24 to/ha dan padatahun 2017 turun menjadi 1,20 ton/ha. Berdasarkan data diatas lada putih men- galami penurunan produktivitas pada lima tahun terakhir. Padahal lada putih merupa- kan salah satu mata pencaharian pokok masyarakat di Provinsi Kepulauan Bangka Belitung, hingga saat ini harga lada putih di Provinsi Kepulauan Bangka Belitung terus mengalami penurunan setiap tahunnya, untuk melihat harga rata-rata pertahun lada putih (Muntok White Pepper) di Provinsi Kepulauan Bangka Belitung dapat dilihat pada Gambar 1.

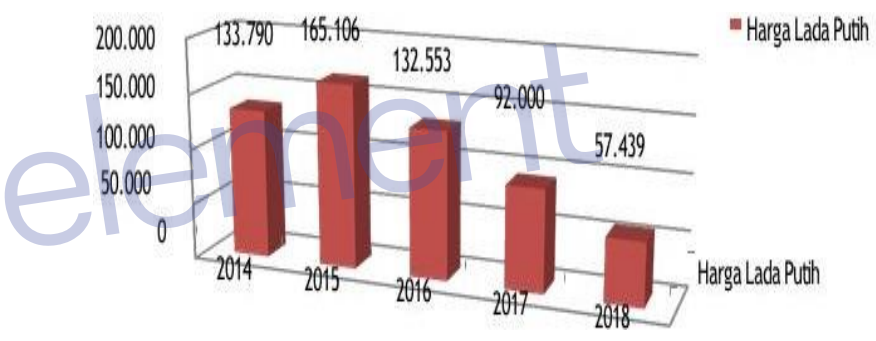

Gambar 1. Harga rata-rata Lada Putih di Provinsi Kepulauan Bangka Belitung

Berdasarkan Gambar 1, harga rata-rata tahunan lada putih di Provinsi Kepulauan Bangka Belitung ditingkat petani mengalami trend, harga lada putih meningkat pada tahun 2014 namun terjadi penurunan terus menerus dari tahun 2015 hingga sekarang. Salah satu kabupaten yang memiliki kontribusi dalam total produksi terbesar kedua di Provinsi Kepulauan Bangka Belitung adalah Kabupaten Bangka Barat dengan Jumlah produksi sebesar 4.906 ton setelah Kabupaten Bangka Selatan dengan jumlah sebesar 17.009 ton dilanjutkan dengan Kabupaten Belitung, Bangka, Bangka tengah, dan terakhir Belitung Timur.

Kabupaten Bangka Barat merupakan salah satu wilayah yang berkontribusi terhadap pengembangan sektor pertanian di Provinsi Kepulauan Bangka Belitung. Kabupaten Bangka 


\section{Barat yang berpusat di}

Kota Muntok memiliki enam kecamatan diantaranya, yaitu Kecamatan Kelapa, Tempilang, Simpang Teritip, Jebus, Parit tiga dan Muntok. Kabupaten Bangka Barat merupakan daerah yang strategis ditinjau dari sudut geografisnya. Hal ini dikarenakan posisi Kabupaten Bangka Barat yang dekat dengan Pulau Sumatera sehingga menjadikan wilayah ini sebagai pintu gerbang keluar masuknya barang dan penumpang dari luar pulau Bangka melewati jalur laut. Permasalahannya pada survei awal yang dilakukan ke petani dapat diketahui bahwa petani lada putih di Kabupaten Bangka Barat menjual hasil produksi lada putih kepada pedagang pengumpul lada putih yang ada di desa tempat tinggal mereka, sehingga para petani tidak leluasa menjual hasil produksinya kepada pedagang besar yang mungkin menawarkan harga yang lebih tinggi dibandingkan dengan pedagang pengumpul yang ada di desa. Hal ini terjadi karena, pedagang pengumpul lada putih di desa memberikan bantuan berupa modal dan peralatan untuk usahatani lada putih, oleh sebab itu para petani menjual hasil produksi lada putih mereka kepada pedagang pengumpul sebagai balas jasa. Harga lada putih yang terus menurun disebabkan distribusi yang kurang baik, dalam permasalahan ini menyangkut informasi pasar terutama informasi mengenai harga serta informasi tentang kebutuhan lada putih di pasar. Perantara pemasaran lada putih lebih cepat memperoleh informasi harga dibandingkan petani produsen.

Menurut Baye (2010), perubahan harga pada pasar dapat ditentukan oleh struktur pasar. Perilaku pasar dan kinerja pasar tersebut. Struktur pasar akan menggambarkan tipe dan jenis pasar yang terbentuk sehingga harga yang ditentukan sesuai dengan jenis pasar tersebut, apakah monopoli, oligopoli, atau persaingan sempurna. Selain itu, harga memiliki peran yang sangat penting dalam menentukan tingkat pendapatan uang diperoleh petani, para pedagang, dan organisasi bisnis pad umumnya (Umar et al., 2011).

Berdasarkan uraian tersebut, secara umum penelitian ini dilakukan dengan tujuan untuk menganalisis dan mengetahui apakah pemasaran lada putih (Muntok White Pepper) yang ada di Kabupaten Bangka Barat sudah efisien dengan menggunakan alat analisis pendekatan market structure, market conduct, dan market performance (SCP) yaitu untuk melihat bagaimana pemasaran lada putih dan apakah dalam pemasarannya sudah baik dilihat dari struktur pasar, perilaku pasar dan kinerja pasar maka diperlukan alternatif saluran pemasaran yang efisien sehingga seluruh lembaga pemasaran yang terlibat memperoleh kepuasan dengan adanya aktivitas pemasaran dan keberlanjutan komoditas lada putih (Muntok White Pepper) di Kabupaten Bangka Barat.

\section{TINJAUAN PUSTAKA}

\subsection{Pemasaran}

Khotler (2004) berpendapat bahwa pemasaran adalah suau proses sosial dan managerial yang di dalamnya individu dan kelompok mendapatkan apa yang mereka butuhkan dan inginkan dengan mencip- takan, menawarkan, dan mempertukarkan produk yang bernilai kepada pihak lain. Menurut Asmarantaka (2014), pemasaran adalah proses manajemen yang mengidentifikasi, mengantisipasi dan me- nyediakan apa yang dikehendaki pelang- gan secara efisien dan nilai ekonominya menguntungkan. Nilai ekonomi itu sendiri menentukan harga barang dan jasa. Faktor penting dalam menciptakan nilai tersebut adalah produksi, pemasaran, dan konsum- si. Pemasaran menjadi penghubung antara produksi dan konsumsi sehingga sistem pemasaran merupakan suatu kesatuan kon septual yang secara fisik terdiri dari bagianbagian yang bekerja bersama dalam suatu kesatuan yang terorganisasi. Kegiatan pemasaran ini, aktifitas pertukaran merupakan hal sentral. Pertukaran merupakan kegiatan pemasaran dimana seseorang berusaha menawarkan sejumlah barang atau jasa dengan sejumlah nilai keberbagai ke- lompok sosial untuk memenuhi kebu- tuhannya. Pemasaran sebagai kegiatan 
manusia diarahkan untuk memuaskan keinginan dan kebutuhan melalui proses pertukaran. Bila ditinjau dari segi ekonomi, kegiatan pemasaran merupakan kegiatan produktif karena memberikan kegunakan benda, waktu, tempat dan hak milik.

\subsection{Saluran Pemasaran}

Kotler (2008), mendefinisikan saluran pemasaran merupakan suatu saluran distribusi (channel of distribution) dianggap mencakup suatu kelompok lembaga- lembaga yang melaksanakan keseluruhan kegiatan (fungsi) untuk mengalihkan produk disertai hak miliknya dari lingkungan produksi ke arah lingkungan konsumsi. Saluran pemasaran merupakan suatu jalur dari lembaga-lembaga pemenyalur yang mempunyai kegiatan menyalurkan barang dari produsen ke konsumen. Penyalur ini secara aktif akan mengusahakan perpindahan bukan hanya secara fisik tapi dalam arti agar barang-barang tersebut dapat dibeli konsumen. Saluran distri- busi atau saluran pemasaran merupakan suatu alur yang dilalui oleh arus barang- barang dari produsen ke perantara dan akhirnya sampai pada pemakai. Saluran pemasaran merupakan suatu struktur unit organisasi dalam perusahaan dan luar pe- rusahaan yang terdiri atas agen, dealer, pedagang besar, pengecer, melalui mana sebuah komoditas, produk atau jasa dipasarkan.

Menurut Limbong dan Sitorus (1985), saluran pemasa- ran adalah rangkaian lembaga-lembaga ta- taniaga yang dilalui barang dalam penyalu-ran dari produsen ke konsumen dimana di dalamnya terlibat beberapa lembaga pemasaran.

\subsection{Efisiensi Pemasaran}

Efisiensi pemasaran menurut Sofjan (2015), merupakan suatu bentuk dari nisbah antara total biaya dengan total nilai produk yang dipasarkan. Indikator yang biasanya digunakan untuk menentukan efisiensi pemasaran menurut Sudiyono (2002), adalah margin pemasaran, harga di tingkat konsumen, tersedianya fasilitas fisik pemasaran serta intensitas persaingan pasar. Efisiennya suatu pemasaran menurut
Asmarantaka (2009) akan dapat tercipta jiká pihak-pihak yang terlibat baik produsen, lembaga-lembaga pemasaran maupun konsumen mem- peroleh suatu kepuasan. Semakin besarnya biaya pemasaran yang dikeluarkan bila dibandingkan dengan nilai dari produk yang), akan menyebabkan pasar menjadi tidak efisien. Dengan kata lain, semakin besar biaya pemasaran yang dikeluarkan maka margin pemasarannya akan semakin besar dan me- nyebabkan tidak efisiennya sistim pemasa- ran yang berlangsung.

\subsection{Konsep Strukture, Conduct, and Performance (SCP)}

Model SCP ini pertama kali dikemukakan oleh Joe Bain dalam bukunya "Indus- trial Organization" yang menjelaskan hub- ungan yang dapat diramalkan antara struktur, perilaku, dan kinerja pasar. Dahl dan Hammond (1977) menjelaskan bahwa analisis pemasaran dapat dikaji melalui struktur, perilaku dan kinerja pasar. Pada awalnya paradigma SCP merupakan pen- dekatan yang umumnya digunakan untuk mengkaji hubungan dinamika persaingan suatu industri dengan kinerjanya. Paradigma SCP pada awalnya digunakan untuk mengkaji pembentukan organisasi industri. Namun dalam perkembangannya pendekatan SCP ini telah banyak digunakan dalam pemasaran komoditas pertanian. Karena menurut Soekartawi (1993), pendekatan SCP merupakan teknik yang relatif baru untuk meningkatkan efisiensi dan sekaligus memperhatikan wel-fare sociaty. Hubungan paling sederhana dari ketiga variable yaitu Structure - Conduct

- Performance adalah hubungan linier di- mana struktur mempengaruhi perilaku kemudian perilaku mempengaruhi kinerja. Komponen struktur, perilaku, dan kinerja tersebut saling mempengaruhi termasuk adanya faktor-faktor lain seperti teknologi, progresivitas, strategi, dan usaha-usaha un- tuk mendorong penjualan. Struktur struc- ture) suatu usaha akan menentukan bagaimana perilaku suatu usaha (conduct) yang pada akhirnya menentukan kinerja (performance) usaha tersebut. 


\subsection{Kerangka Pemikiran}

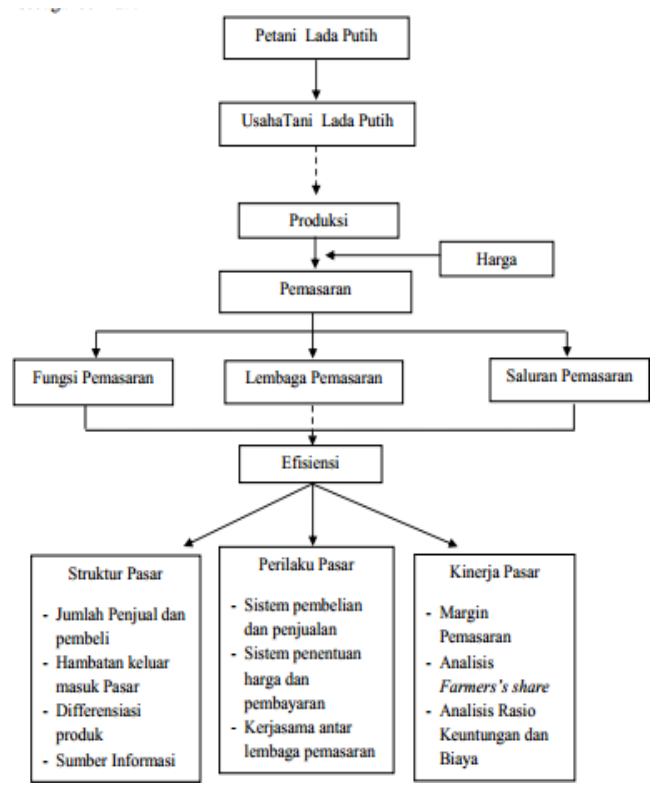

\section{METODOLOGI PENELITIAN}

Penelitian ini dilakukan di Kabupaten Bangka Barat mulai pada Bulan Agustus 2018 sampai dengan Bulan Mei 2019. Penentuan daerah penelitian ini dilakukan dengan sengaja (purposive sampling). Daerah yang dipilih sebagai tempat penelitian adalah Kabupaten Bangka Barat, dengan memilih tiga Kecamatan yaitu Simpang Teritip, Kelapa dan Tempilang. Dasar pertimbangan pemilihan daerah penelitian, karena ketiga desa yang dipilih merupakan desa dengan jumlah kontribusi yang cukup tinggi di Kabupaten Bangka Barat. Metode penelitian yang digunakan dalam penelitian ini adalah metode survei. Alat analisis yang digunakan adalah deskriptif kualitatif dan pendekatan SCP. Populasi pada penelitian ini berjumlah 116 petani yang melakukan usahatani lada putih (muntok white pepper) dan telah melakukan penjualan hasil panen lada putih, populasi diambil dari enam desa yaitu Desa Bukit Terak, Desa Air Menduyung, Desa Kacung, Desa Pusuk, Desa Penyampak dan Desa Sangku, yang

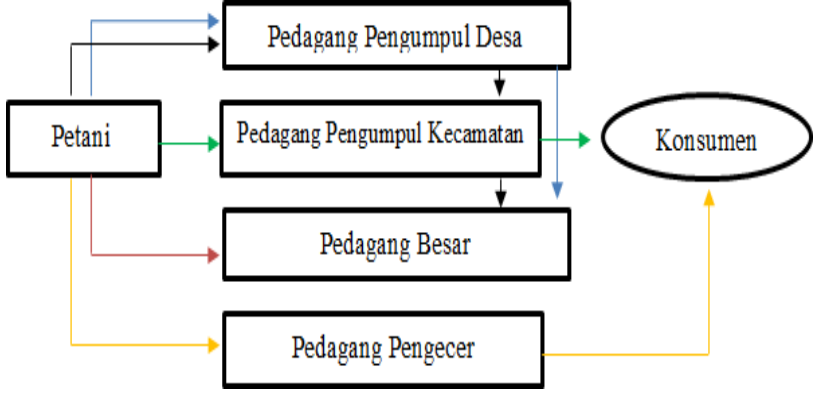

akan dijadikan responden penelitian. Penentuan besarnya sampel yang akan digunaan untuk penelitian dengan rumus Slovin sebagai berikut:

$$
n=N / N(e)^{2+1}
$$

keterangan:

$\mathrm{n}$ = besaran

sampel $\mathrm{N}=$

besaran populasi

e $\quad=$ Persen kelonggaran ketidaktelitian

karena kesalahan penarikan sampel (5\%)

Data yang digunakan pada penelitian ini terdiri dari dua jenis data, yaitu data primer dan sekunder. Data primer berasal dari pelaku pemasaran lada putih yaitu 90 petani lada putih, 10 pedagang pengumpul desa, 7 pedagang pengumpul kecamatan, 3 pedagang besar dan 5 pedagang pengecer. Data sekunder merupakan data time series harga lada putih lima tahun terakhir, jumlah ekspor lima tahun terakhir yang bersumber dari Dinas Perkebunan Provinsi Bangka Belitung dan Badan Pusat Statistika Provinsi Bangka Belitung.

\section{HASIL DAN PEMBAHASAN}

Fungsi pemasaran ada 3 pokok:

- Fungsi pertukaran fungsi ini berhubungan dengan perpindahan hak milik dari barang/jasa yang dipasarkan, meliputi kegiatan pembelian dan kegiatan penjualan.

- Fungsi Fisik adalah semua tindakan yang berhubungan dengan transportasi/ pengangkutan, penyimpanan, dan pengolahan.

- Fungsi fasilitas berhubungan dengan standarisasi, penanggungan resiko, pembiayaan, dan informasi pasar.

\subsection{Analisis Saluran Pemasaran}

Berdasarkan hasil penelitian yang telah dilakukan dapat dijelaskan mengenai saluran pemasaran lada putih (Muntok white pepper) di Kabupaten Bangka Barat.

Hasil penelitian yang telah dilaksanakan pada pemasaran lada putih di Kabupaten Bangka Barat menunujukan ada empat saluran pemasaran dapat dilihat pada Gambar 2 berikut ini:

Gambar 2. Saluran Pemasaran Lada Putih 
di Kabupaten Bangka Barat Tahun 2019

Berdasarkan gambar tersebut ada 5 saluran pemasaran di Kabupaten Bangka Barat saluran pertama (panah hitam) yaitu petani-pedagang pengumpul desapedagang pengumpul kecamatan-pedagang besar dengan jumlah petani 6 orang atau $6,6 \%$, saluran kedua (panah biru) yaitu petani-pedagang desa-pedagang besar dengn jumlah petani 12 orang atau 13,3\%, saluran ketiga (panah merah) yaitu petanipedagang besar dengan jumlah petani 30 orang atau 33,3\%, saluran keempat (panah hijau) yaitu petani-pedagang pengumpul kecamatan-konsumen dengan jumlah petani 34 orang atau $37,7 \%$, dan saluran kelima (panah kuning) yaitu petani- pedagang pengecer-konsumen dengan jumlah petani 8 orang atau $8,8 \%$.

\subsection{Analisis Struktur Pasar}

Analisis struktur pasar dilakukan dengan mengacu kepada Sumardi (2009), yaitu analisis struktur pasar ditentukan berdasarkan hasil identifikasi dari jumlah dan ukuran lembaga pemasaran, sifat produk, serta hambatan keluar masuk pasar. Berdasarkan hasil penelitian di lapangan, struktur pasar dianalisis dengan

melihat jumlah penjual dan pembeli, diferensiasi produk dan hambatan keluar masuk pasar. Penjelasan mengenai struktur pasar yang dihadapi para pelaku lembaga pemasaran dalam pemasaran lada putih (muntok white pepper) di Kabupaten Bangka Barat dapat dilihat pada Tabel 1.

Tabel 1. Struktur Pasar Lada Putih (Muntok white pepper) di Kabupaten Bangka Barat Tahun 2019

\begin{tabular}{llllcc}
\hline $\begin{array}{l}\text { Lembaga } \\
\text { ?emasaran }\end{array}$ & $\begin{array}{l}\text { Jumlah } \\
\text { Penjual }\end{array}$ & $\begin{array}{c}\text { Jumlah } \\
\text { Pembeli }\end{array}$ & $\begin{array}{c}\text { Diferensiasi } \\
\text { Produk }\end{array}$ & $\begin{array}{c}\text { Hambatan } \\
\text { Keluar } \\
\text { Masuk Pasar }\end{array}$ & $\begin{array}{c}\text { Struktur } \\
\text { Pasar }\end{array}$ \\
\hline PR & 90 & 25 & Tidak ada & Rendah & Oligopsoni \\
PB & 3 & $>25$ & Tidak ada & Rendah & Oligopoli \\
PPD & 10 & $>25$ & Tidak ada & Rendah & Oligopoli \\
PPK & 7 & $>25$ & Tidak ada & Rendah & Oligopoli \\
PP & 5 & $>25$ & Tidak ada & Rendah & $\begin{array}{c}\text { Persaingan } \\
\text { semnnuma }\end{array}$ \\
& & & & & \\
\hline
\end{tabular}

Pada Tabel 1, diketahui struktur pasar lada putih di Kabuaten Bangka Barat yang terbentuk lebih mengarah pada pasar persaingan tidak sempurna yaitu oligopoli pada lembaga pemasaran tingkat pedagang besar, pedagang pengumpul desa dan pedagang pengumpul kecamatan. Hal ini dikarenakan penentuan harga di kuasai oleh lembaga pemasaran yang membeli.

Pada lembaga pemasaran petani responden struktur pasar yang terbentuk adalah oligopsoni, hanya pada tingkat pedagang pengecer yang merupakan persaingan sempurna karena pada proses penentuan harga masih ada yang melakukan tawarmenawar.

\subsection{Analisis Perilaku Pasar}

Perilaku pasar lada putih (muntok white pepper) dianalisis dengan mengamati praktek penjualan dan pembelian, sistem penentuan dan pembayaran harga, dan ker- jasama diantara lembaga-lembaga pemasa- ran. Hubungan antara pembeli dan penjual merupakan hubungan persaingan (Asmarantaka, 2014). Uraian mengenai perilaku pasar yang dilakukan oleh para pelaku pemasaran dalam pemasaran lada putih (muntok white pepper) di Kabupaten Bangka Barat terdapat pada Tabel 5.

Tabel 5. Perilaku Pasar Antara Tingkat Lembaga Pemasaran Lada Putih di Kabupaten Bangka Barat Tahun 2019

\begin{tabular}{llllc}
\hline $\begin{array}{c}\text { Lembaga } \\
\text { Pemasaran }\end{array}$ & $\begin{array}{c}\text { Tujuan } \\
\text { Penjualan }\end{array}$ & Kerjasama & $\begin{array}{c}\text { Proses Penentuan } \\
\text { Harga }\end{array}$ & $\begin{array}{c}\text { Sistem Pembayaran } \\
\text { Harga }\end{array}$ \\
\hline PR & PB & PR-PPD & Ditentukan PB & Tunai \\
& PPD & PR-PPK & $\begin{array}{l}\text { Ditentukan PPD } \\
\text { Dunai }\end{array}$ \\
& PPK & & $\begin{array}{l}\text { Ditentukan PPK } \\
\text { Tawar-menawar }\end{array}$ & Tunai \\
PB & PP & & Tunai \\
PPD & PLN & PB-PLN & Ditentukan PLN & Tunai \\
& PB & PPD-PPK & Ditentukan PB & Tunai \\
PPK & PPK & & Ditentukan PPK & Berangsur \\
& PB & PPK-PLW & Ditentukan PB & Tunai \\
& PLW & & Ditentukan PPK & Tunai \\
PP & Konsumen & - & Tawar-menawar & Tunai \\
\hline
\end{tabular}

a. Pembelian dan Penjualan

Setiap lembaga pemasaran lada putih (muntok white pepper) di Kabupaten Bangka Barat melakukan kegiatan pembelin dan penjualan. Kegiatan pemasaran lada putih dimulai 
sejak panen yang dilakukan pada pagi hari dan dilakukan oleh petani responden sendiri atau mengupah orang lain (tenaga kerja harian). Kegiatan pembelian dimulai ketika pedagang pengumpul, pedagang besar, dan pedagang pengecer membeli lada putih dari petani responden. Sistem transaksi jual beli yang dilakukan antara petani responden dan lembaga pemasaran aalah sistem bukti dimana lembaga pemasaran yang terlibat ikut menyaksikan dan mengetahui berapa banyak jumlah lada putih yang di perjual belikan.

b. Sistem Penentuan Harga

Sistem penentuan harga lada putih banyak ditentukan oleh lembaga pemasaran karena lebih mengetahui informasi perkembangan perkembangan harga yang berlaku dipasar dibandingkan dengan petani responden. Sistem pembayaran lada putih di berbagai tingkat lembaga pemasaran adalah tunai namun pada tingkat pedagang pengumpul kecamatan ada yang berangsur karena tidak menggunakan modal pribadi melainkan akan membayar setelah lembaga pembeli selanjutnya telah membeli lada putih tersebut.

c. Kerjasama Antar Lembaga Pemasaran Kerja sama yang dilakukan oleh petani responden dan lembaga pemasaran lada putih tidak terikat atau tidak formal dan tanpa kontrak tertulis.

Bentuk kerjasama yang dilakukan antar pelaku pemasaran hanya dalam bentuk sederhana yaitu adanya ikatan kekerabatan anatar petani dan lembaga pemasaran sehingga adanya kepercayaraan dan berlangganan dalam proses jual beli lada putih. Ada pula yang sebagian lembaga pemasaran memberikan berupa pinjaman modal ke petani, sehingga petani akan menjual hasil lada putih ke lembaga pemasaran yang memberikan bantuan pinjaman dengan maksud untuk membalas budi.

\subsection{Analisis Kinerja Pasar}

1. Analisis Marjin Pemasaran

Perhitungan marjin meliputi biaya pemasaran dan keuntungan lembaga yang terlibat dapat dilihat pada Tabel 3 .

Tabel 3. Analisis Marjin Pemasaran Lada Putih (Muntok White Pepper) di Kabupaten Bangka Barat Tahun 2019

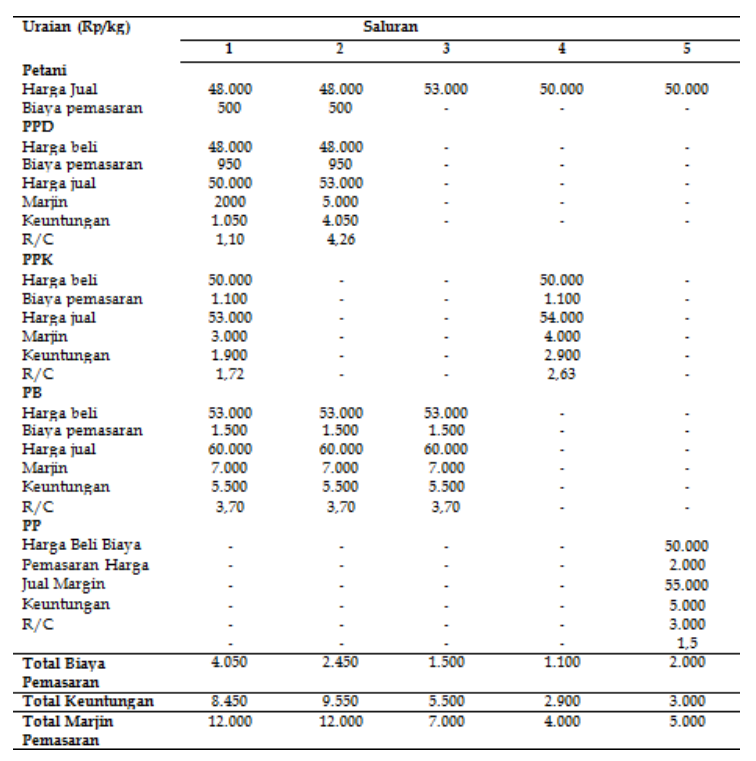

Pada Tabel 3, diketahui total biaya pemasaran dan total margin terbesar berada pada saluran I yaitu Rp 4.050 dan Rp 12.000, sedangkan total biaya pemasaran dan total margin pemasaran terkecil berada pada saluran IV yaitu Rp 1.100 dan Rp.4000.

\section{Analisis Farmer's Share}

Besarnya bagian yang diterima petani responden lada putih (muntok white pepper) untuk masing-masing saluran pemasaran dapat dilihat pada Tabel 4.

Tabel 4. Farmer's Share pada Saluran Pemasaran lada putih (muntok white pepper) di Kabupaten Bangka Barat Tahun 2019

\begin{tabular}{cccc}
\hline $\begin{array}{c}\text { Saluran } \\
\text { Pemasaran }\end{array}$ & $\begin{array}{r}\text { 'Harga di Tingkat } \\
\text { Petani responden } \\
(\mathrm{Rp} / \mathrm{Kg})\end{array}$ & $\begin{array}{r}\text { 'Harga di Tingkat } \\
\text { Konsumen } \\
(\mathrm{Rp} / \mathrm{Kg})\end{array}$ & $\begin{array}{r}\text { Farmer's } \\
\text { Share }(\%)\end{array}$ \\
\hline I & 48.000 & 60.000 & 80,00 \\
II & 48.000 & 60.000 & 80,00 \\
III & 53.000 & 60.000 & 88,33 \\
NV & 50.000 & 54.000 & 92,59 \\
$V$ & 50.000 & 55.000 & 90,90 \\
\hline
\end{tabular}


Pada Tabel 4, diketahui saluran IV merupakan saluran yang memiliki jumlah Farmer's Share terbesar yaitu 92,59 persen diikuti oleh saluran $\mathrm{V}$ yaitu 90,90 dan saluran yang memiliki jumlah terkecil berda pada saluran I dan II yaitu dengan jumlah yang sama sebesar 80,00 persen.

3. Analisis Ratio Keuntungan dan Biaya Pemasaran

Rasio keuntungan dan biaya pemasa- ran merupakan salah satu alat ukur efisiensi pemasaran yang digunakan untuk melihat sebaran keuntungan dan biaya yang dikeluarkan oleh lembaga pemasaran. Rasio keuntungan dan biaya pada masing-masing lembaga lada putih (muntok white pepper) di Kabupaten Bangka Barat dapat dilihat pada Tabel 5.

Tabel 5. Rasio Keuntungan dan Biaya Pada Saluran Pemasaran Lada Putih (Muntok White Pepper) di Kabupaten Bangka Barat Tahun 2019

\begin{tabular}{cccc}
\hline $\begin{array}{c}\text { Saluran } \\
\text { Pemasaran }\end{array}$ & $\begin{array}{c}\text { Keuntungan } \\
\text { Pemasaran }(\mathrm{Kp} / \mathrm{Kg})\end{array}$ & $\begin{array}{c}\text { Biaya Pemasaran } \\
(\mathrm{Rp} / \mathrm{Kg})\end{array}$ & $\begin{array}{c}\text { Rasio Keuntungan } \\
\text { dan Biaya }\end{array}$ \\
\hline I & 8.450 & 4.050 & 2,08 \\
II & 9.550 & 2.450 & 3,89 \\
II & 5.500 & 1.500 & 3,66 \\
IV & 2.900 & 1.100 & 2,63 \\
V & 3.000 & 2.000 & 1,50 \\
\hline & & &
\end{tabular}

Berdasarkan tabel diatas rasio keuntungan dan biaya pada setiap saluran pemasaran lada putih (muntok white pepper) di Kabupaten Bangka Barat memiliki nilai lebih dari satu, hal ini menunjukkan bahwa kegiatan pemasaran yang dilakukan oleh lembaga pada masing-masing saluran pemasaran sudah memberikan keuntungan.

4. Efisiensi Pemasaran

Tingkat efisiensi pemasaran dapat diukur berdasarkan hasil analisis marjin, farmer's share dan rasio keuntungan terhadap biaya. Saluran yang efisien berdasar- kan analisis marjin pemasaran adalah salu- ran yang memiliki nilai marjin paling ren- dah. Berdasarkan kelima saluran pemasa- ran yang ada, saluran yang memiliki nilai total marjin terendah adalah saluran IV, yai- tu sebesar Rp 4.000.
Tingkat efisiensi ber- dasarkan farmer's share adalah saluran yang memiliki nilai farmer's share terbesar. Nilai farmer's share terbesar terdapat pada saluran IV dengan nilai farmer's share sebesar 92,59 persen, dikarenakan pada saluran IV petani responden menjual langsung kepada peda- gang pengumpul tingkat kecamatan tanpa melibatkan lembaga pemasaran lainnya. Nilai rasio keuntungan terhadap biaya terbesar diperoleh pada saluran II, yaitu sebesar 3,89. Namun nilai rasio keuntungan dan biaya dengan jumlah terbesar tidak dapat menjadi patokan bahwa saluran ter- sebut efisien. Hal ini sejalan dengan penelitian Ita (2018), berdasarkan analisis rasio keuntungan terhadap biaya, saluran yang efisien adalah saluran yang memiliki nilai rasio keuntungan terhadap biaya terbesar tetapi harus memperhatikan nilai margin dan farmer's share.

Nilai Efisiesi pemasaran lada putih (muntok white pepper) dapat dilihat pada Tabel 6.

Tabel 6. Nilai Efisiensi Pemasaran Pada Saluran Pemasaran Lada Putih (Muntok White Pepper) di Kabupaten Bangka Barat Tahun 2019

\begin{tabular}{cccc}
$\begin{array}{c}\text { Saluran } \\
\text { pemasaran }\end{array}$ & $\begin{array}{c}\text { Marjin } \\
\text { Pemasaran }\end{array}$ & $\begin{array}{c}\text { Farmer's Share } \\
(\%)\end{array}$ & $\begin{array}{c}\text { Rasio } \\
\text { Keuntungan } \\
\text { dan Biaya }\end{array}$ \\
\hline I & 12.000 & 80,00 & 2,08 \\
II & 12.000 & 80,00 & 3,89 \\
III & 7.000 & 88,33 & 3,66 \\
IV & 4.000 & 92,59 & 2,63 \\
V & 5.000 & 90,90 & 1,50 \\
\hline
\end{tabular}

\section{PENUTUP}

\subsection{Simpulan}

Berdasarkan hasil penelitian maka dapat diambil beberapa kesimpulan sebagai berikut :

1. Terdapat lima macam saluran pemasa- ran lada putih (muntok white pepper) di Kabupaten Bangka Barat diantaranya:

a. Saluran I yaitu petani respondenpedagang pengumpul desa - pedagang pengumpul kecamatan - pedagang besar; b. Saluran II yaitu petani re- sponden pedagang pengumpul desa - pedagang besar; c. Saluran III yaitu petani responden 
- pedagang besar;

d. Saluran IV yaitu petani responden pedagang pengumpul kecamatan konsumen; e. Saluran V yaitu petani responden - pedagang pengecer konsumen.

2. Struktur pasar yang terbentuk dari pemasaran lada putih (muntok white pepper) di Kabupaten Bangka Barat ada- lah: 1. Pasar yang terbentuk pada petani responden mendekati pasar pasar oligopsoni,; 2. Pasar yang terbentuk pada pedagang besar, pedagang pengumpul desa dan pedagang pengumpul kecamatan mendekati pasar oligopoli,; 3. Pasar yang ter- bentuk pada pada pedagang pengecer cenderung mendekati pasar persaingan sempurna. Perilaku pasar yang terjadi terdiri dari kegiatan penjualan dan pembelian dilakukan oleh setiap lem- baga pemasaran atas dasar ke- percayaan. Sistem penentuan harga dil- akukan dengan cara tawarmenawar dan/atau ditentukan oleh lembaga pemasaran berdasarkan harga yang berlaku di pasar internasional dan pembayaran dilakukan secara tunai dan ada juga yang dibayar secara berangsur. Kerjasama yang dilakukan lembaga pemasaran secara tidak terikat dan tanpa kontrak tertulis. Saluran IV merupakan saluran yang relatife lebih efisien di ukur berdasarkan nilai marjin, farmer's share, dan $\mathrm{R} / \mathrm{C}$ rasio. Karena memliki nilai marjin terkecil yakni Rp 4.000, nilai farmer's share sebesar 92,59, dan rasio keuntungan terhadap biaya sebesar 2,63.

\subsection{Saran}

Saran yang dapat peneliti sampaikan adalah :

1. Diharapkan petani responden lada putih yang ada di Kabupaten Bangka Barat untuk lebih aplikatif memilih saluran pemasaran yang relatife lebih efisien serta dapat meningkatkan keuntungan bagi petani. Diantara beberapa saluran pemasaran yang ada, saluran IV merupakah saluran yang palin efisien.

2. Diharapkan pemerintah dapat mem- bantu dan memfasilitasi petani re- sponden dalam hal kegiatan pemasaran lada putih (muntok white pepper) di Ka- bupaten Bangka Barat dengan cara membuat sebuah koperasi khusus un- tuk memasarkan hasil panen lada putih yang nantinya apabila ada petani re- sponden yang memiliki hasil produksi sedikit dapat memasarkan hasil panennya ke pedagang besar dengan cara anggota koperasi mengumpulkan hasil produksi di koperasi tersebut.

3. Diharapkan peran penyuluh pertanian khususnya di bidang perkebunan komoditas lada putih khususnya di Kabupaten Bangka Barat dapat lebih memperhatikan petani responden un- tuk memberikan informasi terkait har- ga maupun hal-hal yang berkaitan dengan usahatani lada putih.

\section{Daftar Pustaka}

Asmarantaka RW. 2009. Pemasaran ProdukProduk Pertanian. Di dalam Bunga Rampai Agribisnis Seri Pemasaran. Bogor: Departemen Agribisnis, Fakultas Ekonomi dan Manajemen, Institut Pertanian Bogor.

Asmarantaka RW. 2014. Pemasaran Agribisnis (Agrimarketing). Bogor (ID): IPB Press.

Assauri S. 2015. Manajemen Pemasaran Dasar, Konsep Dan Strategi. Jakarta: PT. Raja Grafindo Persada.

Baye, M. 2010. Managerial economics and Business Strategy, seventh edition. McGraw-Hill Irwin. Singapura.

BAPPEBTI (Badan Pengawas Perdagangan Berjangka Komoditi). 2014. Analisis Harga Lada Hitam/Lada Putih 2014. Badan pengawas perdagangan berjangka komoditi. Jakarta.

Dahl, D. C. and Jerome. W. Hammond. 1977. Market and Price Analysis. The Agricultural Industries. Mc. Graw-Hill Book Company, Inc,United State.

Khotler P. 2004. Manajemen Pemasaran 1 Edisi 
Millenium. PT Indeks Kelompok Gramedia. Jakarta.

Khotler P. 2008. Manajemen Pemasaran 1 Edisi keenam. Jakarta: Erlangga Limbong WH, dan Sitorus P. 1985. Pengantar Tataniaga Pertanian. Jurusan Ilmu sosial Ekonomi Pertanian. Fakultas Pertanian. Bogor: Institut Pertanian Bogor.

Soekartawi. 1993. Prinsip- Prinsop Dasar Ekonomi Pertanian. Jakarta: Rajawali press.

Sudiyono, A. 2002. Pemasaran Pertanian. Universitas Muhammadiyah Malang. Malang

Sumardi. 2009. Sebaran Populasi, Peningkatan Produktivitas Dan Pelestarian Sapi Potong Di Pulau Jawa. Yogyakarta. Fakultas Peternakan Universitas Gadjah Mada.

Umar H. 2011. Metode Penelitian untuk Skripsi dan Tesis Bisnis Edisi 11. Jakarta: PT Raja Grafindo Persada. 